\title{
OTOTOXICITY AS A SIDE-EFFECT OF DRUGS: LITERATURE REVIEW
}

\section{Contributions:}

A Study design/planning

B Data collection/entry

C Data analysis/statistics

D Data interpretation

E Preparation of manuscript

F Literature analysis/search

$\mathrm{G}$ Funds collection

\section{Magdalena Beata Skarzynska ${ }^{1,2,3, A-F}$, Bartłomiej Król ${ }^{3, C-E}$, Lukasz Czajka ${ }^{1,2, E-F}$}

${ }^{1}$ Otorhinolaryngology, Institute of Sensory Organs, Poland

${ }^{2}$ Otorhinolaryngology, Center of Hearing and Speech, Poland

${ }^{3}$ Otorhinolaryngology, Institute of Physiology and Pathology of Hearing, Poland

Corresponding author: Magdalena Beata Skarzynska, Otorhinolaryngology, Institute of Sensory Organs, Mokra 05830, Kajetany, Poland; email: m.skarzynska@csim.pl, Phone: +48501024784

\begin{abstract}
Background: The first reports of drug ototoxicity were documented in the 1940s. Epidemiological data indicate that changes in audiometric image may affect several percent of patients taking ototoxic drugs. Ototoxicity is manifested by hearing loss and/or changes in the vestibular system. Knowledge of mechanisms responsible for ototoxic effects, as well as important physiological parameters of the human body, may be used as a basis for developing guidelines for the pharmacotherapy. The aim of this paper is to draw attention to the scale and nature of adverse effects of ototoxic drugs.

Materials and methods: The review of current literature included the databases PubMed, ResearchGate, GoogleScholar, and ScienceDirect. The studies were reviewed in relation to the inclusion criteria and subsequently evaluated for internal and external validity.

Results: According to the literature, pharmacotherapy using drugs with documented ototoxic potential may cause hearing loss and changes in the vestibular system. Depending on the drugs used, changes may be reversible or irreversible. Pathological changes involve hair cells in Corti's organ, stria vascularis, and cochlear potentials. The effect of drugs may cause dysfunction in psychophysical and psychosocial development, especially important for the pediatric population.
\end{abstract}

Conclusion: The ototoxicity of drugs is well known as a cause of cochlear hearing loss. Due to the nature of these substances and their use, more extensive monitoring of adverse reactions should be introduced, including in clinical trial protocols.

Key words: • drugs $\bullet$ cisplatin $\bullet$ furosemide $\bullet$ hearing loss $\bullet$ ototoxicity $\bullet$ hair cell

\section{OTOTOKSYCZNOŚĆ JAKO DZIAŁANIE NIEPOŻĄDANE STOSOWANIA LEKÓW: PRZEGLĄD LITERATURY}

\begin{abstract}
Streszczenie
Wstęp: Pierwsze doniesienia dotyczące ototoksyczności leków zostały udokumentowane w latach czterdziestych XX wieku. Dane epidemiologiczne wskazują, że zmiany w badanich audiometrycznych mogą dotyczyć od kilku do kilkudziesięciu procent pacjentów przyjmujących leki ototoksyczne. Ototoksyczność objawia się utratą słuchu i / lub zmianami w układzie przedsionkowym. Poznanie mechanizmów odpowiedzialnych za działanie ototoksyczne, jak również ważnych dla organizmu człowieka parametrów fizjologicznych, może być podstawą do opracowania wytycznych dla farmakoterapii. Celem artykułu jest zwrócenie uwagi na skalę i charakter działań niepożądanych leków ototoksycznych.

Materiał i metody: Przegląd aktualnej literatury dokonano na podstawie naukowych baz danych: PubMed, ResearchGate, GoogleScholar i ScienceDirect. Badania zostały ocenione pod względem założonych kryteriów włączenia, a następnie ocenione pod kątem trafności wewnętrznej i zewnętrznej materiału.
\end{abstract}

Wyniki: Zgodnie z danymi literaturowymi farmakoterapia lekami o udokumentowanym potencjale ototoksycznym może powodować utrate słuchu oraz zmiany w układzie przedsionkowym. W zależności od zastosowanych leków zmiany mogą mieć charakter odwracalny lub nieodwracalny. Zmiany patologiczne obejmują komórki słuchowe w narządzie Cortiego, prążki naczyniowe i oddziałują na potencjały ślimakowe. Działanie leków może powodować zaburzenia w rozwoju psychofizycznym i psychospołecznym, szczególnie istotne dla populacji pediatrycznej.

Wnioski: Ototoksyczność leków jest dobrze znaną badaczom przyczyną niedosłuchu ślimakowego. Ze względu na charakter stosowania tych substancji, należy wprowadzić możliwie szeroki program monitorowania działań niepożądanych, $\mathrm{w}$ tym również na etapie badań klinicznych.

Słowa kluczowe: leki • Cisplatyna • Furosemid • utrata słuchu • ototoksyczność • komórki słuchowe

\section{Introduction}

Hearing loss is a problem that affects people in all cultures, and is also known as the fourth cause of long-term disability in people. It is estimated that it affects between 6 and $8 \%$ of the world's population, which translates into 500 million people with hearing loss. To understand the scale of the development of the problem, in 1985 it was estimated that hearing loss affected about 42 million people; nowadays the number is more than 10 times higher, which could be due to, among others, increased exposure to noise and the use of ototoxic drugs [1]. 
The concept of ototoxicity can be described as a functional disorder and cellular degeneration of the inner ear tissues caused by therapeutic measures, the effect of which is to contribute to the loss of hearing and/or vestibular function, evident as tinnitus or dizziness [2,3]. Ototoxicity is a wellknown side-effect of drugs which can have wide-ranging consequences on a patient's future quality and standard of living, although in certain cases the benefit of drugs will outweigh the risk of hearing loss. Ototoxicity is particularly dangerous for children, as its occurrence can have a significant impact on their future psychosocial development and subsequent adult life. Known ototoxic drugs include aminoglycoside antibiotics, cytostats-platinum derivatives, loop diuretics, and antimalarial drugs. Importantly, ototoxic side-effects in some cases disappear after cessation of pharmacotherapy, so the effect can be temporary or permanent. However, the ototoxicity of certain groups of drugs, such as the aminoglycoside antibiotics (AGs), produce a permanent effect in terms of hearing loss [3]. The purpose of this paper is to review the current information on the ototoxic effects of medicines currently used in pharmacotherapy and the possibilities of preserving hearing.

\section{Anatomy and physiology of the ear}

Anatomically, the human ear consists of 3 functional parts: the outer ear, middle ear, and inner ear. Each of these parts is responsible for sound transmission and reception. The outer ear (the external ear + ear canal) reflects and amplifies incoming sound and transmits it in turn to the middle ear. The outer ear allows one to locate a sound source in the vertical plane. The middle ear begins with the eardrum (a thin membrane about $9 \mathrm{~mm}$ in diameter) followed successively by three bones (hammer, anvil, and stirrup) which transmit mechanical pressure of sound from the eardrum to the inner ear. In the inner ear, sound is converted into hydraulic waves in the cochlea, which stimulate the sensory hair cells lining the organ of Corti, releasing neurotransmitters that trigger the eighth cranial nerve and transmitting neural impulses through the brain stem to the auditory cortex in the temporal lobe of the brain. Although ears are fully formed at birth, the maturation of neural pathways and auditory structures takes place during infancy and early childhood, making small children particularly susceptible to the ototoxic effects of pharmacotherapy $[3,4]$.

\section{Material and methods}

To ensure a proper selection of studies and impartiality of the review process, the peer-reviewed articles were identified according to the protocol's inclusion criteria. A search model was developed, taking into account the search terms and databases searched. The criteria for inclusion in the review were:

\section{Studies published between 1964 and 2020 .}

2. Studies had to address the ototoxicity associated with aminoglycosides (AG), cisplatin (CIS), loop diuretics (LD), chloroquine (CQ), hydroxychloroquine (HCQ), and be part of an ototoxicity monitoring program.

3. Studies in English, German, Portuguese, French, or Polish were considered.
4. The studies were identified by keyword and $\mathrm{MeSH}$ terms searched in the electronic databases PubMed, Scopus, Web of Science, and Science Direct.

\section{Exclusion criteria were:}

1. Articles in languages other than English, German, Portuguese, French, or Polish.

\section{Purely theoretical publications, grey subject matter.}

3. Publications on the ototoxicity of drugs other than aminoglycoside antibiotics, cisplatin, diuretics, chloroquine, and hydroxychloroquine.

Search strategy: Search of the literature - abstracts and articles - was conducted by the same researcher. The search was conducted using the terms: aminoglycoside antibiotics + ototoxicity; cisplatin + ototoxicity; loop diuretics + ototoxicity, chloroquine / hydroxychloroquine + ototoxicity; ototoxicity monitoring. References cited in each publication, review, or book chapter were reviewed for additional potential publications. The search took place in April 2020.

Qualification of appropriate records for analysis: The literature search for literature and their analysis according to inclusion and exclusion criteria was conducted by one researcher. The search identified 3565 records in four databases: PubMed $(n=631)$, Scopus $(n=738)$, Science Direct $(n=1255)$, and Web of Science $(n=941)$. Duplicate records were deleted, leaving 1211 titles/abstracts for review; 75 articles were retrieved for full text screening.

\section{Results}

\section{Ototoxicity of aminoglycoside antibiotics}

Aminoglycoside antibiotics (AGs) are a class of antibacterial compounds discovered in the 1940s. Despite the risk of permanent ototoxicity, aminoglycosides remain a commonly utilized group of antibiotics worldwide due to their efficiency in treating severe and life-threatening bacterial infections and low cost. The group of these drugs shows a wide spectrum of action against some strains of aerobic Gramnegative bacteria, and have thus found wide application in the treatment of TB [2,5]. In addition, aminoglycosides are used to treat pulmonary exacerbations in patients with cystic fibrosis and are on the list of preparations recommended by the WHO for the treatment of sepsis infections in newborns. Frequent prescribing of this group of drugs has led to documentation of a wide range of effects, but an important factor is the low treatment cost [6].

However, in recent years there has been a decline in the use of these agents, particularly in developed countries, due to their significant toxicity and the availability of better alternatives on the market $[2,5]$. Among the most commonly used drugs in this group are dihydrostreptomycin, triamycin, kanamycin, amikacin, and gentamicin. The mechanism of action of the aminoglycosides is based on disturbing the integrity of the bacterial cell membrane by impairing the process of bacterial protein synthesis, thus preventing further development of bacterial cells and weakening the protective functions of the cell membrane. The molecular 
process takes place by permanent binding to the $30 \mathrm{~S}$ ribosome subunit, joining at the A-translation site (A-accelerated acceptor). This leads to a misreading of the genetic code and inhibits the translocation process. Finally, it leads to the accumulation of protein dysfunctions and final death of the bacteria [7].

Aminoglycosides are known to show their toxicity both in the vestibular system affecting balance, but also show a toxic effect on cochlear cells affecting the hearing organ. This is mainly due to the loss of cochlear and/or vestibular hair cells. The ototoxic effects of AGs vary from a few to as much as $33 \%$ in the case of hearing loss, and in the case of the vestibular system, up to $15 \%$ of patients who receive these drugs intravenously. It may also affect patients taking medication in the form of ear drops, especially those with perforated eardrum or tympanostomy tube. Gentamycin, triamycin, and streptomycin are preferentially atria-toxic, while amikacin and kanamycin are primarily cochlear-ototoxic (8-10,125-127). According to the clinical and scientific reports, some mitochondrial mutations (particularly $1555 \mathrm{~A}>\mathrm{G}$ mutation in the mitochondrial gene MTRNR1) have been strongly associated with the onset of the aminoglycoside-induced deafness [11]. The impairment of RNA translation after exposure to aminoglycosides within sites on mitochondrial $12 \mathrm{~S}$ rRNA was mapped at nucleotide 1555 in the $12 \mathrm{~S}$ rRNA gene (an adenine-to-guanine mutation). Other gene mutations that can raise susceptibility to ototoxicity of AGs include C1494T, which is less common than the A1555G mutation [12,13].

Ototoxicity is the most serious adverse effects of AG therapy, due to the mitochondrial mutations that target the cochlea (but not the vestibular organs) [14]. One possible scenario to explain the molecular ototoxicity of AGs is that AGs may cause misreading in the mitochondrial synthesis of protein and a decrease in mitochondrial ATP synthesis. This results in compromised (reduced) ion pump activity and this reduction in strial intermediate cells may lead for example to a decrease in the endocochlear potential and consequently to progression of hearing loss [14]. Hair cells responsible for higher frequencies are more susceptible to AG ototoxicity than those responsible for lower frequencies.

According to pharmacokinetics, aminoglycosides are detected in the cochlea a few minutes after systemic administration. Fluorescently labeled AGs, gentamicin for example, was detected in the stria vascularis of the mouse within 10 minutes after injection (systemic administration), mainly in marginal cells next to intermediate and basal cells as well as fibrocytes. As a result, gentamicin enters fluids of the inner ear from capillaries of the stria through the marginal cells. Consequently, in the organ of Corti, fluorescently labeled gentamicin was detected 1 hour after injection and detected intracellularly in the hair cell after 3 hours. The entry of AGs into various cochlear structures shows how complex, anatomically and physiologically, the uptake mechanism of AGs is into the inner ear [15].

In summary, the possible entry sites for AGs into scala media are threefold: via stria vascularis, basilar membrane, or Reissner's membrane, and for the two last entry is also possible through and between the marginal cells. A possible entry site is via mechanotransducer channels located on stereocilia of hair cells, ATP receptors, TRP channels, or endocytosis on the apical or basolateral membranes [16-21]. Aminoglycosides cause apoptotic cell death directly or indirectly, in this way increasing formation of ROS (reactive oxygen species) or free radicals [22-29].

Aminoglycoside molecules are not in themselves ototoxic. Their activity in redox reactions with metals derived from biomolecules is essential [30]. This process involves chelating metal ions as a result of the activity of aminoglycosides. These successively chelated metal complexes show their activity in redox reactions and produce reactive oxygen species (ROS), responsible for inducing oxidative damage [31]. As shown in studies, the ferro-aminoglycoside complex may exacerbate ROS-induced cell damage in the inner ear leading to apoptotic or necrotic cell death [32-36]. The nature of ROS-dependent ototoxicity is confirmed by the fact that prevention or replacement of ROS protects against drug ototoxicity, as confirmed in an animal model $[24,35,36]$.

In patients treated with aminoglycosides, hearing loss is initially observed at high frequencies, due to early damage to the hair cells at the base of the cochlea, which then extend to the apical cells of the cochlea (the area responsible for detecting low frequency sounds). The level of hair cell damage, and the resulting hearing loss, is directly proportional to the dose of medication to which the hair cells are exposed. Importantly, this loss is either permanent or reversible. Losses can be assessed using basic audiological studies such as pure tone audiometry and/or otoacoustic emissions (OAE), but these studies are not routinely performed under clinical conditions $[5,36,128]$. Loss of speech perception develops later on as damage to the higher ganglia and lower frequencies widens. Furthermore, aminoglycosides persist in inner ear tissues for 6 months or more, which suggests that the hearing loss may begin straight after treatment, but the link between pharmacological treatment and hearing loss may not be immediately apparent $[36,37]$. Older people are more susceptible to hearing damage as they have significantly fewer hair cells and their endogenous defence mechanisms may be reduced. In addition, this potential can be increased by taking several groups of ototoxic drugs at once, such as loop diuretics [2].

However, a meta-analysis comparing once-a-day versus multiple-daily regimes of administration of aminoglycosides did not see a statistically significant correlation between the frequency of AG administration and ototoxicity [38]. According to relevant literature, one of the main susceptibility factors is a genetic predisposition of ototoxicity to aminoglycosides. Between 17 to $33 \%$ of patients who experience ototoxicity after AG treatment have a genetic predisposition to it [39]. One of the first sites targeted by aminoglycosides is the small subunit of mitochondrial ribosomes [40,41].

\section{Ototoxicity of cytostats}

Cisplatin (cis-diaminodichloridoplatin (II)), carboplatin, and oxaliplatin belong to the group of the most commonly used anticancer drugs. All these drugs show ototoxic sideeffects. However, cisplatin is the oldest drug in this group; it is the most commonly prescribed platinum drug, but is 
also the most ototoxic $[42,129,130]$. It is a well-known chemotherapeutic agent used in both children and adults, primarily for the treatment of malignant neoplasms: osteomyosarcoma, germ cell, liver, immature neuroblastoma, embryonic tumor, head and neck cancer, and some cancers of the central nervous system [43]. During pharmacotherapy with cisplatin, peripheral neuropathy, nephrotoxicity, nausea and vomiting have been reported in patients, as well as ototoxicity. Ototoxicity may occur within several hours or days after cisplatin treatment. Hearing loss appears to be dose-dependent and has been characterized as progressive, irreversible, bilateral, and may be accompanied by tinnitus and dizziness $[43,44]$. Hearing loss progresses, initially from the high frequencies, and patients have difficulty hearing hissing-type sounds and speech in noisy environments. The hearing loss can then progress to lower frequencies [45].

The exact mechanism of cisplatin-induced hearing loss involves several correlating mechanisms. One mechanism is a model of antioxidants in which cisplatin produces reactive oxygen species (ROS) in the cochlea, which results in exhaustion or reduction of antioxidant molecules such as glutathione or antioxidant enzymes. This translates into peroxidation of lipids, which can involve increased levels of butyraldehyde and other toxic peroxides of lipids and aldehydes. These substances may cause an increased inflow of calcium ions and cause apoptosis of cells in the cochlea [46-48]. Another possible mechanism for cisplatin's ototoxicity is that the drug activates the oxidase isoform of nicotinamidoadenine 3-dinucleotide phosphate (NOX3). Activation of NOX3 contributes to the production of toxic 4-hydroxynonenal aldehyde as a result of the reaction of a hydroxyl radical with unsaturated fatty acids in the double-layer cell wall. This results in an increased inflow of calcium to outer hair cells leading to cell apoptosis [48-50]. The third mechanism of cisplatin ototoxicity is the activation of transient potentials of the vanilloid 1 channel receptor (TRPV1) in cochlear hair cells. This leads to the growth of calcium ions in the cell, activation of NOX3, and activation of a transcription factor, signal transducer, and transcription 1 activator (STAT1), eventually causing hair cell death [45,51-53].

The ototoxic effect of cisplatin takes place in three areas of the cochlea: hair cells in the organ of Corti, spiral ganglion cells, and lateral wall tissue (spiral ligament and stria vascularis). It has been shown that each of the outer hair cells, stria, and spiral ligament cells undergo apoptosis, and the immunoreactivity of platinized DNA has been localized in the nuclei of the outer hair cells and the cells of the stria and spiral ligament [2].

\section{Ototoxicity of diuretics}

Diuretics can be divided into four specific classes depending on where they affect ion capture. A distinction is made between loop diuretics, whose place of capture is a thicker, growing part of Henle's loops. The place of operation of thiazide diuretics is the distal and cortical parts of the connecting channel. For potassium-saving diuretics, the mechanism of action is based on activity against cells in the cortical, aldosterone-sensitive collective channels. Acetazolamide and mannitol act in the proximal duct. The mechanism of action of loop diuretics is mainly based on affecting the transport of sodium, potassium, and chlorine ions in distal parts of Henle loop cells in the kidneys; in this way, they inhibit reabsorption. Furosemide was the first loop diuretic approved by the Food and Drug Administration in 1966, and another approved drug from this group was ethacrynic acid, approved in 1967. Shortly after approval, it was observed that ethacrynic acid has a high level of ototoxicity, so furosemide has been the first drug of choice for the next four decades $[54,55]$. The mechanism of action of diuretics against cochlear potentials relates to changes in cell electrical currents: direct-current endothelial potential; sound-induced alternating currents, cochlear microphone potential, DC summing potential, and complex action potential. Loop diuretics are involved in temporary hearing loss, as a single injection of ethacrynic acid causes the positive components of endothelial potentials in the striae to be completely eliminated, although they reversibly recover over time [56,131]. The amplitude of the cochlear microphonic potential, which depends on the flow of ions in the endolymphatic space between the epidermal platelet and the inside of the hair cells, is then reduced. The change in endothelial potential causes a cascade of changes in the amplitude of the cochlear microphonic. Subsequently, there are changes in the DC summing potential, driving it to a high positive level, regardless of physiological state. As the endothelial potential and the cochlear microphonic evolve over time, the DC summing potential returns to normal. The cascade of changes in the previously mentioned potentials affect the complex potentials that depend on them, causing rapid and significant decreases in amplitude [57]. Early scientific reports on the effects of loop diuretics of furosemide and ethacrynic acid have shown permanent degeneration in cochlear cells after a single administration [58-63]. However, subsequent studies with animal models have shown that single administration of loop diuretics causes temporary damage or swelling of the stria vascularis and side-wall of the cochlea. This is followed by damage to the peripheral cells and swelling of the intermediate cells as well as the interdental space. After administering diuretics, no direct damage to cochlear and vestibular hair cells, ganglion neurons, or vestibular ganglion neurons was observed in the examined animals. Pathological edema of stria vascularis occurs 30 minutes after administration of the drug and subsequently disappears over a day $[57,60,64-67]$. The clinical nature of the ototoxicity of loop diuretics is seen in the development of sensorineural hearing loss in patients; however, the symptoms may be permanent or reversible. The expression of symptoms may be dependent on the dose of the drugs taken and the concurrent burden on patients [66]. This relationship is conditioned by the pharmacokinetic profile of drugs and physiological parameters of the body. Loop diuretics show a high ability to bind to plasma proteins and are subject to liver metabolism and excretion by the kidneys, so patients with liver and kidney failure are particularly susceptible to ototoxicity.

The explanation of the mechanism responsible for inducing ototoxicity through the use of loop diuretics has not been clearly indicated. However, stria vascularis cells are considered to be the primary target of these drugs. The molecular mechanism of ototoxicity was originally considered to include ATPase $\mathrm{Na}^{+}$and $\mathrm{K}^{+}$and adenyl cyclase [68]. In 
further studies it was confirmed as a secondary dependency $[69,70]$. It is also suggested that the ototoxicity in the diastema involves a system of cotransporters for sodium, potassium, and chlorine ions causing a disturbance in the ionic homeostasis of the endolymph, due to the ionic grip points for loop diuretics. The blocking of the marginal canals in the cochlea with medication causes the accumulation of sodium in the intervertebral space, resulting in the retention and accumulation of water. The endothelial potential decreases, the electrochemical gradient decreases, and hearing thresholds increase [71]. However, this dependence is a secondary effect, as the endothelial potential is immediately inhibited before the cotransporters are inhibited [65]. Stria vascularis cells, on which the influence of loop diuretics are observed, have been described. One report is not unambiguous: the literature reports that these drugs may cause edema of the peripheral cells and shrinkage of intermediate cells; other researchers have reported shrinkage of the peripheral cells and swelling of intermediate cells $[66,72,73]$. The vagueness of these reports may suggest the occurrence of variable effects of loop diuretics on the dilatation of cells [71]. New reports shed light on the effect of these drugs on blood flow through stria vascularis, where the total blood flow was inhibited after administration of ethacrynic acid to the guinea pig, proving possible ischemia. Further analysis allowed observations of the relationship to be made, proving that inhibition of blood flow in the lateral wall of the cochlea happens much earlier than enzyme inactivation and inhibition of $\mathrm{Na}-\mathrm{K}-2 \mathrm{Cl}$ cotransport in stria vascularis. Moreover, it suggests that microcirculation obstruction in the lateral wall of the cochlea may be the earliest lesion caused by ethacrynic acid, consistent with its rapid action on the endothelial potential. Delayed inactivation of metabolic enzymes and inhibition of $\mathrm{Na}-\mathrm{K}-2 \mathrm{Cl}$ is most likely a secondary effect of ischemia and hypoxia $[57,61]$. The description of two cases in the Santos and Nadol study confirms previous reports that the ototoxicity of furosemide is dose-dependent and that symptoms are represented by edema and cystic edema of stria vascularis [74]. This is confirmed by previous reports of cytological changes found in the stria vascularis of cochlear vessels and dark cells of the vestibular system in patients who were given loop diuretics [63]. It is also important that simultaneous exposure of patients to other groups of ototoxic drugs when combined with loop diuretics may exacerbate the occurrence of side-effects.

\section{Ototoxicity of antimalarial drugs}

Quinine is an alkaloid known since the 16th century and obtained from the bark of the cinchona tree. Chloroquine (CQ), invented in the 1940s, and its analogue hydroxychloroquine (HCQ), are long-established and widely used antimalarial drugs. They are also used in autoimmune diseases such as lupus erythematosus, or rheumatoid arthritis (RA) accompanied by discoid lupus, because of their immunomodulatory properties [75]. As is known, these drugs are widely used in therapy, and their action is considered safe, although they have documented side-effects, and the border between a therapeutic dose and a toxic dose is narrow. An overdose may be associated with cardiovascular disorders that pose a risk to patient health, but, importantly from the point of view of our analysis, it may also cause ototoxic side-effects $[76,77]$.
Patients who are treated with chloroquine or hydroxychloroquine report symptoms suggesting ototoxic effects. In these patients, sensory and neural hearing loss, tinnitus, imbalance (especially after a long period of use), and cochlear-mandibular symptoms have been observed. In the Bernard study, in a group of 74 patients treated with chloroquine phosphate in 13 patients, abnormalities were observed in auditory evoked potentials from the brainstem. As a result, for 12 patients the therapy was discontinued and symptoms afterwards abated. In one patient where it was necessary to continue the therapy, permanent hearing loss was observed [78]. Johanson et al. reported irreversible hearing loss in two patients treated with chronic hydroxychloroquine for lupus erythematosus [79].

Seçkin et al. also reported the ototoxic effect of HCQ in a patient who was treated for RA. In this case, it was a mild side-effect, as the unwanted symptoms of sensory and nervous hearing loss and tinnitus reverted under the medication and the audiogram parameters returned to normal after 2 months [80]. Further evidence describing the ototoxic effects of HCQ was the case of a 7-year-old patient with pulmonary hemosyderosis described by Coutinho and Duarte, where unilateral sensory and neural hearing loss occurred as a result of continuous HCQ intake over a 2-year period [81]. The adverse reactions after administration of these drugs were in some cases temporary, but cases of permanent hearing or vestibular dysfunction have also been reported $[82,83,133]$.

The specific mechanism of action of these ototoxic drugs is not known, but their toxicity is considered to be related to long-term exposure or administration of high doses. As a result, this results in accumulation of the drugs or add to the side-effects from other simultaneously administered drugs. CQ and HCQ accumulate selectively in tissues associated with melanocytes, which are highly represented in retinal cells, hair follicles, and glands which have internal secretion. In addition, melanocyte cells are also represented in the inner ear, especially in well-vascularized loci. In this case, the accumulation of CQ or HCQ contributes to vascular damage and degenerative changes in the planum samilatum and stria cells [82]. It is known that ototoxicity is correlated with the accumulation of CQ and HCQ, and as a result may contribute to the destruction of stereocilia, reduction of the neuronal population, and changes in support structures, leading to ischemia of the auditory system $[80,84,85]$. Ototoxicity due to CQ may manifest as both auditory and vestibular dysfunction. It is usually mild to moderate, bilateral, and symmetrical. Hearing is usually restored after cessation of use, but when similar side-effects occur when taking other drugs at the same time, the effect may be irreversible $[78,83,86,87]$.

\section{Ototoxicity monitoring}

Hearing loss as a result of the side-effects of drugs may cause a number of changes in psychophysical and psychosocial development, especially in the pediatric population. For children's speech development, the consequences of sensory deficits, such as hearing loss, can be particularly disastrous. Since the development of spoken language is highly dependent on hearing, hearing impairment is considered a serious disability; it can cause speech 
delays, learning difficulties, and social and emotional disorders [88]. The nature of possible actions, and the scale of the possible problem, entail the necessity to provide these patients with additional care in the form of monitoring for ototoxic side-effects, mentioned as early as 1984 by Fausti et al. $[89,90]$. Ototoxicity monitoring is a term that describes the early identification of changes in hearing test parameters. It allows early detection of changes in hearing as a result of taking medication. At the same time, it allows the attending physician to introduce changes in pharmacotherapy protocols as early as possible, reducing the dose of prescribed medication, or altering the pharmacotherapy profile completely. This avoids further development of damage to the hearing system. The introduction of ototoxicity monitoring also allows for early intervention in patients who have already developed changes in their hearing system. This intervention makes it possible to restore hearing performance, improve comfort (with a limited amount of effort), and to improve communication with the family. Unfortunately, however, it is not always possible to change the treatment profile, as was the case with a 7-yearold patient with pulmonary hemosiderosis described by Coutinho and Duarte: despite 2 years of using hydroxychloroquine and with signs of ototoxicity, the drug was not discontinued. The reason was that in this case effective treatment of the disease took priority over the occurrence of ototoxic side-effects [81].

The nature of progressive ototoxic changes is classically from base to apex. Hearing changes start at high frequencies and move to lower frequencies, depending on treatment time and/or dosage. Monitoring may provide the first preclinical evidence of hearing damage, even before evidence of hearing loss is seen in conventional tests. The clinical effects of these changes, and the awareness of their importance, has led to the recognition that increased levels of screening to reveal the exact side-effects of ototoxic drugs are needed. The detailed processes of monitoring are not the same for all substances and it essentially depends on the suspected profile of the lesions. Aminoglycosides and chemotherapeutics (platinum-based) are widely and frequently used drugs with known ototoxic potential, with deterioration of high frequency hearing in the early stages. Thus, the process of detecting changes focuses on the analysis of high frequencies $[91,92]$.

Loop diuretics, antimalarial drugs, and other drugs with known ototoxic potential (salicylates, but also aminoglycosides and platinum chemotherapeutics) can interact in a way that affects other than high frequencies, so additional audiometric studies also need to be conducted. In such cases, it is logical to introduce audiological tests such as speech audiometry to assess hearing in the speech range $(0.25-8 \mathrm{kHz})$. The essence of such monitoring is to detect deviations that are characteristic of adverse effects.

The proper planning and conduct of the clinical ototoxicity monitoring process entails selecting appropriate clinical hearing tests. In addition, consideration also needs to be given to ototoxicity monitoring during the clinical evaluation of the efficacy of drugs at the clinical trial stage. According to current knowledge, not every new clinical trial protocol mentions the need for audiological studies. The Food and Drug Administration (FDA) guidelines impose the obligation to monitor ototoxicity, but only if studies are conducted on drugs from a group where the potential for ototoxic side effects has already been proven [93].

In practice, three basic audiological tests are used to assess ototoxic effects on the cochlea: basic audiological evaluation, high-frequency audiometry (HFA), and measurement of otoacoustic emissions (OAEs) $[91,93,94]$. The nature of the tests performed varies in terms of their potential for use, reliability, and the group of patients in which the test can be performed. The monitoring process should take into account each of these tests, used either as a single diagnostic method or in combination. Essentially, the ideal scheme for correctly assessing the impact of drugs on the auditory system is audiological testing, which is first performed before the administration of the drug, allowing for a transparent interpretation of the results. In such a scheme, the first diagnostic test procedures performed should be as broad as possible, providing a basis for further analysis and exclusion of other accompanying episodes during continued administration of the drug. The following tests should be considered: pure tone thresholds in the conventional frequency range, HFA, tympanometry, speech audiometry, and OAEs. In the basic versions of the tests, frequencies up to $8 \mathrm{kHz}$ are assessed, not assessing losses above this frequency. If there are changes in the range up to $8 \mathrm{kHz}$, then tests should be done to assess the loss at higher frequencies. In addition, patients treated for otitis media should undergo a basic tympanometry test. If there is hearing loss in the $0.25-8 \mathrm{kHz}$ range, a word recognition test may be performed. Underlining all these test results should be an analysis comparing the results of the tests performed prior to the beginning of the treatment procedures [92].

In addition to these basic audiological tests, audiologists may consider, if justified, the use of validated tests to assess tinnitus and dizziness, which can be carried out using distance testing techniques. In specific cases, hearing may be assessed using an auditory brainstem response (ABR) test, which evaluates changes in the central auditory system $[91,95,96]$. This method is particularly useful for testing infants, coma, or dementia patients where a behavioral test cannot be used. For most of the ototoxic drugs used, the primary symptom is cochlear toxicity, which can be expressed as sensorineural hearing loss. The earliest effects of ototoxic drugs tend to be manifested by the outer hair cells (OHCs) of the basal cochlear turn. The most sensitive test to detect a significant number of cochlear lesions is the high frequency audiometry (HFA) test, which involves an air conduction threshold test for frequencies above $8 \mathrm{kHz}$ (up to 16 or $20 \mathrm{kHz}$ ) to detect changes, before moving down into the speech range $[93,95,97,134]$.

Otoacoustic emission (OAE) tests can also be an aid in monitoring the ototoxicity of drugs. For clinical evaluation, there are spontaneous OAEs (SOAEs), which occur in the absence of a stimulus; transient OAEs (TOAEs), which occur in response to repeated transient stimuli; and distortion product OAEs (DPOAEs), which use two stimuli of different frequencies introduced simultaneously into the auditory canal. Lonsbury-Martin \& Martin (2001) report that DPOAEs can detect ototoxic changes earlier than TEOAEs, especially since DPOAEs can be measured 
at a higher frequency than TEOAEs. DPOAEs are more sensitive to the frequency areas of the cochlea where damage first occurs, and DPOAEs can often be recorded in the presence of more severe sensorineural hearing loss than TEOAE $[93,98-103,131]$.

In summary, the use of various forms of monitoring for the ototoxicity of drugs is essential to monitor adverse reactions and may form the basis of future remedies [132].

\section{Discussion}

The problem of ototoxic side-effects of drugs - hearing loss or changes in the vestibular system - has been known in the scientific community since the 1940 s, when disorders found after using streptomycin to treat tuberculosis were first reported [104]. In March 2020, the World Health Organization (WHO) reported that more than $5 \%$ of the world's population, representing around 466 million people, has a hearing loss, of which 34 million are children. The figures also indicate that the number of patients with hearing loss could double by 2050, while they report that $60 \%$ of childhood hearing loss is avoidable. In addition, hearing loss affects about one-third of the population over 65 years old. One of the main causes of hearing loss is the side-effect of drugs [105]. Audiometric changes may occur in $33 \%$ of adults treated with aminoglycosides, and atrial toxicity is $4 \%$. In patients taking loop diuretics, the occurrence of ototoxicity occurs in $6-7 \%$ of patients, while in children treated with platinum anticancer therapy up to $61 \%$ of hearing loss is reported [106,107].

The common feature of aminoglycosides antibiotics, loop diuretics, cytostatic platinum-based drugs, and antimalarial drugs is their ototoxic potential. As has been shown, the disorders caused by these drugs are related to effects on the cochlea and vestibular organs; both contain specific mechanoreceptors called hair cells, and damage to them causes hearing loss and balance disorders. At the same time, other therapeutic agents can also give rise to certain mechanisms acting on the hearing organs: for example, antimalarial drugs and loop diuretics cause transient, reversible changes and aminoglycosides and platinum cytostats show significant changes causing death of hair cells [108]. The uncovering of these side-effects has led scientists to new directions of research towards understanding and understanding mechanisms, including molecular mechanisms of hair cell susceptibility to ototoxicity, using animal models such as birds, guinea pigs, and mice. It has been found that mice are resistant to hair cell loss, even with long-term use, even with high doses of drugs [109-116]. Only Taylor et al., in a study using bumetanide and kanamycin in a high-dose administration model, demonstrated hair cell degeneration [117]. The exact mechanism of amplification of aminoglycosides ototoxicity by loop diuretics has not been described; however, the molecular target, a sodium/potassium/chloride ion cotransporter which has a dependence of endothelial potential, are suspected.

The literature unanimously points out that patients treated with platinum cytostatic therapy for cancer, and patients with meningitis, encephalitis, tuberculosis, and cystic fibrosis treated with aminoglycoside antibiotics, are exposed to ototoxic effects. Another new group of patients exposed to side-effects are COVID-19 patients treated with experimental therapy using CQ and HCQ. In addition, scientific publications also mention the particular exposure of patients who have received multi-drug treatment with more than one ototoxic drug [118-120]. Another particularly vulnerable group of patients is the group with a high liver load (alcoholism, patients taking other drugs that burden the liver). Pharmaceutical data indicate that there may be an accumulation of drugs in the liver. Precautions and additional monitoring of ototoxic effects of drugs also apply to patients with renal load (children below 3 years of age and adults over 65 years of age) due to their involvement in the elimination process; vulnerable people also include pregnant women and newborns over 14 days of age [121].

The problem of monitoring side-effects was presented in an analysis conducted by Maru and Malky on a group of respondents clinically related to the monitoring process. Only $60 \%$ of the respondents confirmed the fact of monitoring in the context of cochlear toxicity, and in the case of atrial toxicity monitoring it was only $10 \%$. Moreover, they indicated that $72 \%$ of respondents confirmed the absence of ototoxicity management protocols. From this analysis we also learn that basic tests before the administration of the ototoxic drug were confirmed by only $16 \%$ of the respondents, and just $56 \%$ of respondents confirmed that tests had been performed [122]. This analysis is a transparent criterion for the evaluation of small-scale monitoring studies. A further study has provided evidence that physicians in general are not involved in active monitoring and management of ototoxicity protocols, and because they have first contact with the patient it should be the first part of an effective monitoring chain $[123,124]$.

The guidelines of the American Academy of Audiology highlight the importance of audiologists in monitoring patient hearing, and provide detailed criteria to be used to assess the magnitude of adverse drug reactions: these are the National Cancer Institute (NCI) Common Terminology Criteria for Adverse Events (CTCAE) ototoxicity grades, and Brock's hearing loss grades.

The NCI CTCAE ototoxicity grades for children (with adult guidelines in parentheses) are as follows:

- Degree 1: Threshold shift or loss of 15-25 dB relative to baseline, averaged at two or more contiguous frequencies in at least one ear (the same for adults);

- Degree 2: Threshold shift or loss of $>25-90 \mathrm{~dB}$, averaged at two contiguous test frequencies in at least one ear (same for adults);

- Degree 3: Hearing loss sufficient to indicate therapeutic intervention, including hearing aids (e.g., $>20 \mathrm{~dB}$ bilateral HL in the speech frequencies; $>30 \mathrm{~dB}$ unilateral HL; and requiring additional speech language related services). (Adults: $>25-90 \mathrm{~dB}$, averaged at three contiguous test frequencies in at least one ear);

- Degree 4: Indication for cochlear implant and requiring additional speech language related services. (Adults: profound bilateral hearing loss $>90 \mathrm{~dB} \mathrm{HL}$ ).

Note that for children without a baseline evaluation, baseline thresholds are assumed to be $<5 \mathrm{~dB}$ HL. 
The Brock's Hearing Loss Grades, which were originally designed for children receiving platinum-based chemotherapeutics, are:

Degree 0: Hearing thresholds $<40 \mathrm{~dB}$ at all frequencies; Degree 1: Thresholds $40 \mathrm{~dB}$ or greater at $8 \mathrm{kHz}$; Degree 2: Thresholds $40 \mathrm{~dB}$ or greater at $4-8 \mathrm{kHz}$; Degree 3: Thresholds $40 \mathrm{~dB}$ or greater at $2-8 \mathrm{kHz}$; Degree 4: Thresholds at $40 \mathrm{~dB}$ or greater at $1-8 \mathrm{kHz}$ [93].

These guidelines have been developed for people taking platinum cytostatic drugs; however, patients who have taken other drugs should not be overlooked. These scales can effectively assess the degree of hearing loss in them as well.

There are currently no medicines available on the pharmaceutical market that can be used to restore hearing. Currently, available assistance is confined to the use of hearing aids or cochlear implants to improve hearing performance and significantly improve living comfort. This therapy can significantly reduce the effects of distance, noise, and reverberation on the sound received. In addition, the 2003 guidelines of the Federal Communications Commission in the USA require manufacturers and service providers to provide technologies that can be used by people with hearing aids [122].

\section{Conclusions}

To sum up, the existence of ototoxicity caused by the use of different groups of drugs is known, but there is a need to broaden knowledge in this area and extend research protocols to additional groups of drugs. This will allow doctors to prescribe the safest pharmacotherapeutic methods. In addition, there is a need to increase the monitoring of patients for ototoxic side-effects in order to maximize the detection of harmful effects and apply the earlies possible intervention. There is also the need to educate physicians, pharmacists, audiologists, and other medical professionals in contact with the patient about the possibilities of adverse reactions and likely ways of alleviating the problem.

\section{References}

1. Brown CS, Emmett SD, Robler SK, Tucci DL. Global hearing loss prevention. Otolaryngol Clin North Am, 2018; 51: 575-92.

2. Rybak LP, Ramkumar V. Ototoxicity. Kidney Int, 2007; 72: 931-5.

3. Landier W. Ototoxicity and cancer therapy: Ototoxicity and cancer therapy. Cancer, 2016; 122: 1647-58.

4. Milenkovic I, Schiefer U, Ebenhoch R, Ungewiss J. Aufbau und Funktion der Hörbahn. Ophthalmologe. 2020 Mar 24. https:// doi.org/10.1007/s00347-020-01070-0

5. Guthrie OW. Aminoglycoside induced ototoxicity. Toxicology, 2008; 2499(2-3): 91-6.

6. Laurell G. Pharmacological intervention in the field of ototoxicity. HNO, 2019; 67(6): 434-9.

7. Schacht J, Talaska AE, Rybak LP. Cisplatin and aminoglycoside antibiotics: hearing loss and its prevention. Anat Rec, 2012 295(11): 1837-50.

8. Kitasato I, Yokota M, Inouye S, Igarashi M. Comparative ototoxicity of ribostamycin, dactimicin, dibekacin, kanamycin, amikacin, tobramycin, gentamicin, sisomicin and netilmicin in the inner ear of guinea pigs. Chemotherapy, 1990; 36(2): 155-68.

9. Leis JA, Rutka JA, Gold WL. Aminoglycoside-induced ototoxicity. CMAJ, 2015; 187(1): E52-E52.

10. Ariano RE, Zelenitsky SA, Kassum DA. Aminoglycoside-induced vestibular injury: maintaining a sense of balance. Ann Pharmacother, 2008; 42(9): 1282-9.

11. Foster J, Tekin M. Aminoglycoside induced ototoxicity associated with mitochondrial DNA mutations. Egypt J Med Hum Genet, 2016; 17(3): 287-93.

12. Zhao H, Li R, Wang Q, et al. Maternally inherited aminoglycoside-induced and nonsyndromic deafness is associated with the novel C1494T mutation in the mitochondrial $12 \mathrm{~S}$ rRNA gene in a large Chinese family. Am J Hum Genet, 2004; 74(1): 139-52.

13. Ealy M, Lynch KA, Meyer NC, Smith RJH. The prevalence of mitochondrial mutations associated with aminoglycosideinduced sensorineural hearing loss in an NICU population. Laryngoscope, 2011; 121(6): 1184-6.
14. Tono T, Kiyomizu K, Matsuda K, et al. Different clinical characteristics of aminoglycoside-induced profound deafness with and without the $1555 \mathrm{~A}-->\mathrm{G}$ mitochondrial mutation. ORL J Otorhinolaryngol Relat Spec, 2001; 63(1): 25-30.

15. Wang Q, Steyger PS. Trafficking of systemic fluorescent gentamicin into the cochlea and hair cells. J Assoc Res Otolaryngol, 2009; 10(2): 205-19.

16. Hashino E, Shero M. Endocytosis of aminoglycoside antibiotics in sensory hair cells. Brain Res, 1995; 704(1): 135-40.

17. Richardson GP, Forge A, Kros CJ, Fleming J, Brown SD, Steel KP. Myosin VIIA is required for aminoglycoside accumulation in cochlear hair cells. J Neurosci, 1997; 17(24): 9506-19.

18. Marcotti W, van Netten SM, Kros CJ. The aminoglycoside antibiotic dihydrostreptomycin rapidly enters mouse outer hair cells through the mechano-electrical transducer channels. J Physiol, 2005; 567(Pt 2): 505-21.

19. Steyger PS, Peters SL, Rehling J, Hordichok A, Dai CF. Uptake of gentamicin by bullfrog saccular hair cells in vitro. J Assoc Res Otolaryngol, 2003; 4(4): 565-78.

20. Waguespack J, Ricci A. Aminoglycoside ototoxicity: permeant drugs cause permanent hair cell loss. J Physiol, 2005; 567(Pt 2): 359-60.

21. Darrouzet J, Guilhaume A. Ototoxicité cochléaire comparée de trois antibiotiques: kanamycine, gentamicine, tombramycine. Rev Laryngol Otol Rhinol (Bord.), 1976; 97: 11-12.

22. Lenoir M, Puel JL. Dose-dependent changes in the rat cochlea following aminoglycoside intoxication. II. Histological study. Hear Res, 1987; 26(2): 199-209.

23. Forge A. Outer hair cell loss and supporting cell expansion following chronic gentamicin treatment. Hear Res, 1985; 19(2): $171-82$.

24. Rybak LP, Whitworth CA. Ototoxicity: therapeutic opportunities. Drug Discov Today, 2005; 10(19): 1313-21.

25. Abi-Hachem RN, Zine A, Van De Water TR. The injured cochlea as a target for inflammatory processes, initiation of cell death pathways and application of related otoprotectives strategies. Recent Patents CNS Drug Discov, 2010; 5(2): 147-63.

26. Priuska EM, Schacht J. Formation of free radicals by gentamicin and iron and evidence for an iron/gentamicin complex. Biochem Pharmacol, 1995; 50(11): 1749-52. 
27. Clerici WJ, Hensley K, DiMartino DL, Butterfield DA. Direct detection of ototoxicant-induced reactive oxygen species generation in cochlear explants. Hear Res, 1996; 98(1-2): 116-24.

28. Hirose K, Hockenbery DM, Rubel EW. Reactive oxygen species in chick hair cells after gentamicin exposure in vitro. Hear Res, 1997; 104(1-2): 1-14.

29. Sha SH, Schacht J. Stimulation of free radical formation by aminoglycoside antibiotics. Hear Res, 1999; 128(1-2): 112-8.

30. Schacht J. Biochemical basis of aminoglycoside ototoxicity. Otolaryngol Clin North Am, 1993; 26(5): 845-56.

31. Mylonas M, Malandrinos G, Plakatouras J, et al. Stray Cu(II) may cause oxidative damage when coordinated to the -TESHHK- sequence derived from the C-terminal tail of histone $\mathrm{H} 2 \mathrm{~A}$. Chem Res Toxicol, 2001; 14(9): 1177-83.

32. Wu W-J, Sha S-H, Schacht J. Recent advances in understanding aminoglycoside ototoxicity and its prevention. Audiol Neurootol, 2002; 7(3): 171-4.

33. Song BB, Sha SH, Schacht J. Iron chelators protect from aminoglycoside-induced cochleo- and vestibulo-toxicity. Free Radic Biol Med, 1998; 25(2): 189-95.

34. Song B-B, Schacht J. Variable efficacy of radical scavengers and iron chelators to attenuate gentamicin ototoxicity in guinea pig in vivo. Hear Res, 1996; 94(1-2): 87-93.

35. Sha SH, Schacht J. Antioxidants attenuate gentamicin-induced free radical formation in vitro and ototoxicity in vivo: D-methionine is a potential protectant. Hear Res, 2000; 142(1-2): 34-40.

36. Chen Y, Huang W-G, Zha D-J, et al. Aspirin attenuates gentamicin ototoxicity: from the laboratory to the clinic. Hear Res, 2007; 226(1-2): 178-82.

37. Dulon D, Hiel H, Aurousseau C, Erre JP, Aran JM. Pharmacokinetics of gentamicin in the sensory hair cells of the organ of Corti: rapid uptake and long term persistence. C R Acad Sci III, 1993; 316(7): 682-7.

38. Smyth AR, Bhatt J, Nevitt SJ. Once-daily versus multipledaily dosing with intravenous aminoglycosides for cystic fibrosis. Cochrane Database Syst Rev, 2017; 3(3): CD002009.

39. Fischel-Ghodsian N. Genetic factors in aminoglycoside toxicity. Ann NY Acad Sci, 1999; 884: 99-109.

40. Cox EC, White JR, Flaks JG. Streptomycin action and the ribosome. Proc Natl Acad Sci U. S. A, 1964; 51(4): 703-9.

41. Davies J, Anderson P, Davis BD. Inhibition of protein synthesis by spectinomycin. Science, 1965; 149(3688): 1096-8.

42. Truong MT, Winzelberg J, Chang KW. Recovery from cisplatin-induced ototoxicity: a case report and review. Int J Pediatr Otorhinolaryngol, 2007; 71(10): 1631-8.

43. Roland PS, Rutka JA. Ototoxicity. BC Decker, Hamilton, Ontario, 2004.

44. Dasari S, Tchounwou PB. Cisplatin in cancer therapy: molecular mechanisms of action. Eur J Pharmacol, 2014; 740: 364-78.

45. Brock P, Bellman S. Ototoxicity of cis platinum. Br J Cancer, 1991; 63(1): 159-60.

46. Paken J, Govender CD, Pillay M, Sewram V. Cisplatin-associated ototoxicity: a review for the health professional. J Toxicol, 2016; 2016: 1-13.

47. Gonçalves MS, Silveira AF, Teixeira AR, Hyppolito MA. Mechanisms of cisplatin ototoxicity: theoretical review. J Laryngol Otol, 2013; 127(6): 536-41.

48. Rybak LP. Mechanisms of cisplatin ototoxicity and progress in otoprotection. Curr Opin Otolaryngol Head Neck Surg, 2007; 15(5): 364-9.

49. Rybak LP, Husain K, Morris C, Whitworth C, Somani S. Effect of protective agents against cisplatin ototoxicity. Otol Neurotol, 2000; 21(4): 513-520.
50. Ikeda K, Sunose H, Takasaka T. Effects of free radicals on the intracellular calcium concentration in the isolated outer hair cell of the guinea pig cochlea. Acta Otolaryngol, 1993; 113(2): 137-41.

51. Bánfi B, Malgrange B, Knisz J, Steger K, Dubois-Dauphin M, Krause K-H. NOX3, a superoxide-generating NADPH oxidase of the inner ear. J Biol Chem, 2004; 279(44): 46065-72.

52. Mukherjea D, Jajoo S, Whitworth C, et al. Short interfering RNA against transient receptor potential vanilloid 1 attenuates cisplatin-induced hearing loss in the rat. J Neurosci, 2008; 28(49): 13056-65.

53. Karasawa T, Steyger PS. An integrated view of cisplatin-induced nephrotoxicity and ototoxicity. Toxicol Lett, 2015; 237(3): 219-27.

54. Brater DC. Diuretic therapy. N Engl J Med, 1998; 339(6): 387-95.

55. Drugs@FDA: FDA-Approved Drugs [Internet]. [cited 2020 May 8]. Available from: https://www.accessdata.fda.gov/scripts/cder/daf/

56. Ding D, McFadden SL, Woo JM, Salvi RJ. Ethacrynic acid rapidly and selectively abolishes blood flow in vessels supplying the lateral wall of the cochlea. Hear Res, 2002; 173(1-2): 1-9.

57. Ding D, Liu H, Qi W, et al. Ototoxic effects and mechanisms of loop diuretics. J Otol, 2016; 11(4): 145-56.

58. Ng PS, Conley CE, Ing TS. Deafness after ethacrynic acid. Lancet, 1969; 1: 673-4.

59. Quick CA, Hoppe W. Permanent deafness associated with furosemide administration. Ann Otol Rhinol Laryngol, 1975; 84: 94-101.

60. Forge A, Brown AM. Ultrastructural and electrophysiological studies of acute ototoxic effects of furosemide. Br J Audiol, 1982; 16(2): 109-16.

61. Greger R. New insights into the molecular mechanism of the action of diuretics. Nephrol Dial Transplant, 1999; 14(3): 536-40.

62. Matz GJ, Beal DD, Krames L. Ototoxicity of ethacrynic acid. Demonstrated in a human temporal bone. Arch Otolaryngol, 1969; 90(2): 152-5.

63. Arnold W, Nadol JB, Weidauer H. Ultrastructural histopathology in a case of human ototoxicity due to loop diuretics. Acta Otolaryngol, 1981; 91(5-6): 399-414.

64. Silverstein H, Yules RB. The effect of diuretics on cochlear potentials and inner ear fluids. Laryngoscope, 1971; 81(6): 873-88.

65. Bosher SK. The nature of the ototoxic actions of ethacrynic acid upon the mammalian endolymph system. II. Structuralfunctional correlates in the stria vascularis. Acta Otolaryngol, 1980; 90(1-2): 40-54.

66. Rybak LP. Ototoxicity of loop diuretics. Otolaryngol Clin North Am, 1993; 26(5): 829-44.

67. Ikeda K, Oshima T, Hidaka H, Takasaka T. Molecular and clinical implications of loop diuretic ototoxicity. Hear Res, 1997; 107(1-2): 1-8.

68. Paloheimo S, Thalman R. Influence of "loop" diuretics upon $\mathrm{Na}+\mathrm{K}+$-ATPase and adenylate cyclase of the stria vascularis. Arch Otorhinolaryngol, 1977; 217: 347-59.

69. Marks SC, Schacht J. Effects of ototoxic diuretics on cochlear $\mathrm{Na}+/ \mathrm{K}+-$ ATPase and adenylate cyclase. Scand Audiol Suppl, 1981; 14 Suppl: 131-8.

70. Thalmann I, Kobayashi T, Thalmann R. Arguments against a mediating role of the adenylate cyclase-cyclic AMP system in the ototoxic action of loop diuretics. Laryngoscope, 1982; 92: 589-93.

71. Hirose K, Sato E. Comparative analysis of combination kanamycin-furosemide versus kanamycin alone in the mouse cochlea. Hear Res, 2011; 272(1-2): 108-16. 
72. Pike DA, Bosher SK. The time course of the strial changes produced by intravenous furosemide. Hear Res, 1980; 3(1): 79-89.

73. Santi PA, Lakhani BN. The effect of bumetanide on the stria vascularis: a stereological analysis of cell volume density. Hear Res, 1983; 12(2): 151-65.

74. Santos F, Nadol JB. Temporal bone histopathology of furosemide ototoxicity. Laryngoscope Investig Otolaryngol, 2017; 2(5): 204-7.

75. Nielsen-Abbring FW, Perenboom RM, van der Hulst RJ. Quinine-induced hearing loss. ORL J Oto-Rhino-Laryngol, 1990; 52: 65-8.

76. Hart CW, Naunton RF. The ototoxicity of chloroquine phophate. Arch Otolaryngol, 1964; 80: 407-12.

77. Rynes RI. Antimalarial drugs in the treatment of rheumatological diseases. Br J Rheumatol, 1997; 36(7): 799-805.

78. Bernard P. Alterations of auditory evoked potentials during the course of chloroquine treatment. Acta Otolaryngol, 1985; 99(3-4): 387-92.

79. Johansen PB, Gran JT. Ototoxicity due to hydroxychloroquine: report of two cases. Clin Exp Rheumatol, 1998; 16(4): 472-4.

80. Seçkin U, Ozoran K, Ikinciogullari A, Borman P, Bostan EE. Hydroxychloroquine ototoxicity in a patient with rheumatoid arthritis. Rheumatol Int, 2000; 19(5): 203-4.

81. Coutinho MB, Duarte I. Hydroxychloroquine ototoxicity in a child with idiopathic pulmonary haemosiderosis. Int J Pediatr Otorhinolaryngol, 2002; 62(1): 53-7.

82. Fernandes MR de N, Soares DBR, Thien CI, Carneiro S. Hydroxychloroquine ototoxicity in a patient with systemic lupus erythematosus. An Bras Dermatol, 2018; 93(3): 469-70.

83. Bortoli R, Santiago M. Chloroquine ototoxicity. Clin Rheumatol, 2007; 26(11): 1809-10.

84. Hadi U, Nuwayhid N, Hasbini AS. Chloroquine ototoxicity: an idiosyncratic phenomenon. Otolaryngol Head Neck Surg, 1996; 114(3): 491-3.

85. Figueiredo MC, Atherino CCCT, Monteiro CV, Levy RA. Antimalarials and ototoxicity. Rev Bras Reumatol, 2004; 44(3): 212-4.

86. Sotelo J, Briceño E, López-González MA. Adding chloroquine to conventional treatment for glioblastoma multiforme: a randomized, double-blind, placebo-controlled trial. Ann Intern Med, 2006; 144(5): 337-43.

87. Mukherjee DK. Chloroquine ototoxicity: a reversible phenomenon? J Laryngol Otol, 1979; 93(8): 809-15.

88. Oliveira JAA de, Canedo DM, Rossato M. Otoproteção das células ciliadas auditivas contra a ototoxicidade da amicacina. Rev Bras Otorrinolaringol, 2002; 68(1): 7-13.

89. Fausti SA, Schechter MA, Rappaport BZ, Frey RH, Mass RE. Early detection of cisplatin ototoxicity. Selected case reports. Cancer, 1984; 53(2): 224-31.

90. Jacob LCB, Aguiar FP, Tomiasi AA, Tschoeke SN, de Bitencourt RF. Auditory monitoring in ototoxicity. Rev Bras Otorrinolaringol, 2006; 72(6): 836-44.

91. Fausti SA, Frey RH, Henry JA, Olson DJ, Schaffer HI. Early detection of ototoxicity using high-frequency, tone-burst-evoked auditory brainstem responses. J Am Acad Audiol, 1992; 3(6): 397-404.

92. Campbell KCM, Le Prell CG. Drug-induced ototoxicity: diagnosis and monitoring. Drug Saf, 2018; 41(5): 451-64.

93. American Academy of Audiology. Ototoxicity Monitoring: Position Statement and Practice Guidelines [Internet]. 2009 [cited 2020 May 12]. Available from: https://www. audiology.org/publications-resources/document-library/ ototoxicity-monitoring
94. Campbell KC, Durrant J. Audiologic monitoring for ototoxicity. Otolaryngol Clin North Am, 1993; 26(5): 903-14.

95. Jacobson GP, Newman CW. The development of the Dizziness Handicap Inventory. Arch Otolaryngol Head Neck Surg, 1990; 116(4): 424-7.

96. Newman CW, Sandridge SA, Jacobson GP. Psychometric adequacy of the Tinnitus Handicap Inventory (THI) for evaluating treatment outcome. J Am Acad Audiol, 1998; 9: 153-60.

97. Kopelman J, Budnick AS, Sessions RB, Kramer MB, Wong GY. Ototoxicity of high-dose cisplatin by bolus administration in patients with advanced cancers and normal hearing. Laryngoscope, 1988; 98(8 Pt 1): 858-64.

98. Lonsbury-Martin BL, Cutler WM, Martin GK. Evidence for the influence of aging on distortion-product otoacoustic emissions in humans. J Acoust Soc Am, 1991; 89(4 Pt 1): 1749-59.

99. Lonsbury-Martin BL, Martin GK. The clinical utility of distortion-product otoacoustic emissions. Ear Hear, 1990; 11(2): 144-54.

100. Lonsbury-Martin BL, Martin GK. Evoked otoacoustic emissions as objective screeners for ototoxicity. Semin Hear, 2001; 22: 377-92.

101. Reavis KM, McMillan GP, Dille MF, Konrad-Martin D. Metaanalysis of distortion product otoacoustic emission retest variability for serial monitoring of cochlear function in adults. Ear Hear, 2015; 36(5): e251-60.

102. Constantinescu RM, Georgescu M, Pascu A, et al. Otoacoustic emissions analysers for monitoring aminoglycosides ototoxicity. Rom J Intern Med, 2009; 47(3): 273-8.

103. Stavroulaki P, Apostolopoulos N, Dinopoulou D, Vossinakis I, Tsakanikos M, Douniadakis D. Otoacoustic emissions: an approach for monitoring aminoglycoside induced ototoxicity in children. Int J Pediatr Otorhinolaryngol, 1999; 50(3): 177-84.

104. Schatz A, Bugie E, Waksman SA. The classic: Streptomycin, a substance exhibiting antibiotic activity against gram-positive and gram-negative bacteria. [1944]. Clin Orthop Relat Res, 2005; 437: 3-6.

105. World Health Organization. Deafness and hearing loss [Internet]. [cited 2020 May 13]. Available from: https://www.who. $\mathrm{int} /$ news-room/fact-sheets/detail/deafness-and-hearing-loss

106. Knight KRG, Kraemer DF, Neuwelt EA. Ototoxicity in children receiving platinum chemotherapy: underestimating a commonly occurring toxicity that may influence academic and social development. J Clin Oncol, 2005; 23(24): 8588-96.

107. Mudd, PA. Ototoxicity: Overview, Aminoglycosides, Other Antibiotics. 2020 Feb 28 [cited 2020 May 13]; Available from: https://emedicine.medscape.com/article/857679-overview\#a5

108. Audo I, Warchol ME. Retinal and cochlear toxicity of drugs: new insights into mechanisms and detection. Curr Opin Neurol, 2012; 25(1): 76-85.

109. Brummett RE. Effects of antibiotic-diuretic interactions in the guinea pig model of ototoxicity. Rev Infect Dis, 1981; 3 suppl: S216-223.

110. Forge A, Li L. Apoptotic death of hair cells in mammalian vestibular sensory epithelia. Hear Res, 2000; 139(1-2): 97-115.

111. Gratacap B, Charachon R, Stoebner P. Results of an ultrastructural study comparing stria vascularis with organ of Corti in guinea pigs treated with kanamycin. Acta Otolaryngol, 1985; 99(3-4): 339-42.

112. Rizzi MD, Hirose K. Aminoglycoside ototoxicity. Curr Opin Otolaryngol Head Neck Surg, 2007; 15(5): 352-7. 
113. Wang J, Van De Water TR, Bonny C, de Ribaupierre F, Puel JL, Zine A. A peptide inhibitor of c-Jun N-terminal kinase protects against both aminoglycoside and acoustic trauma-induced auditory hair cell death and hearing loss. J Neurosci, 2003; 23(24): 8596-607.

114. Versnel H, Agterberg MJH, de Groot JCMJ, Smoorenburg GF, Klis SFL. Time course of cochlear electrophysiology and morphology after combined administration of kanamycin and furosemide. Hear Res, 2007;231(1-2): 1-12.

115. Hartman BH, Basak O, Nelson BR, Taylor V, Bermingham-McDonogh O, Reh TA. Hes5 expression in the postnatal and adult mouse inner ear and the drug-damaged cochlea. J Assoc Res Otolaryngol, 2009; 10(3): 321-40.

116. Oesterle EC, Campbell S, Taylor RR, Forge A, Hume CR. Sox 2 and JAGGED1 expression in normal and drug-damaged adult mouse inner ear. J Assoc Res Otolaryngol, 2008;9(1): 65-89.

117. Taylor RR, Nevill G, Forge A. Rapid hair cell loss: a mouse model for cochlear lesions. J Assoc Res Otolaryngol, 2008; 9(1): 44-64.

118. Landier W, Knight K, Wong FL, et al. Ototoxicity in children with high-risk neuroblastoma: prevalence, risk factors, and concordance of grading scales - a report from the Children's Oncology Group. J Clin Oncol, 2014; 32(6): 527-34.

119. Parsons SK, Neault MW, Lehmann LE, et al. Severe ototoxicity following carboplatin-containing conditioning regimen for autologous marrow transplantation for neuroblastoma. Bone Marrow Transplant, 1998; 22(7): 669-74.

120. Gao J, Tian Z, Yang X. Breakthrough: Chloroquine phosphate has shown apparent efficacy in treatment of COVID-19 associated pneumonia in clinical studies. Biosci Trends, 2020; 14(1): 72-3.

121. Verdel BM, van Puijenbroek EP, Souverein PC, Leufkens HGM, Egberts ACG. Drug-related nephrotoxic and ototoxic reactions : a link through a predictive mechanistic commonality. Drug Saf, 2008; 31(10): 877-84.

122. Maru D, Malky G-A. Current practice of ototoxicity management across the United Kingdom (UK). Int J Audiol, 2018; 57(sup 4): S76-88.

123. Khoza-Shangase K. Is there a need for ototoxicity monitoring in patients with HIV/AIDS? Afr J Pharm Pharmacol, 2010; 4(9): 574-9.
124. Khoza-Shangase K, Jina K. Ototoxicity monitoring in general medical practice: exploring perceptions and practices of general practitioners about drug-induced auditory symptoms. IPP, 2013; 1(3): 250-59.

125. Lanvers-Kaminsky C, Zehnhoff-Dinnesen AA, Parfitt R, Ciarimboli G. Drug-induced ototoxicity: Mechanisms, pharmacogenetics, and protective strategies. Clin Pharmacol Ther, 2017; 101(4): 491-500.

126. Al-Malky G, Dawson SJ, Sirimanna T, Bagkeris E, Suri R. Highfrequency audiometry reveals high prevalence of aminoglycoside ototoxicity in children with cystic fibrosis. J Cyst Fibros, 2015; 14: 248-54.

127. Hemmingsen D, Mikalsen C, Hansen AR, Fjalstad JW, Stenklev NC, Klingenberg C. Hearing in schoolchildren after neonatal exposure to a high-dose gentamicin regimen. Pediatrics, 2020; 145(2): e20192373.

128. Ogier JM, Lockhart PJ, Burt RA. Intravenously delivered aminoglycoside antibiotics, tobramycin and amikacin, are not ototoxic in mice. Hear Res, 2020; 386: 107870.

129. Gersten BK, Fitzgerald TS, Fernandez KA, Cunningham LL. Ototoxicity and platinum uptake following cyclic administration of platinum-based chemotherapeutic agents. J Assoc Res Otolaryngol, 2020.

130. Budai B, Prekopp P, Noszek L, et al. GSTM1 null and GSTT1 null: predictors of cisplatin-caused acute ototoxicity measured by DPOAEs. J Mol Med, 2020; 98: 963-71.

131. Paken J, Govender CD, Pillay M, Sewram V. Perspectives and practices of ototoxicity monitoring. S Afr J Commun Disord, 2020; 67(1): e1-10.

132. Joo Y, Cruickshanks KJ, Klein BEK, Klein R, Hong O, Wallhagen MI. The contribution of ototoxic medications to hearing loss among older adults. J Gerontol A Biol Sci Med Sci, 2020; 75(3): 561-6.

133. Prayuenyong P, Kasbekar AV, Baguley DM. Clinical implications of chloroquine and hydroxychloroquine ototoxicity for COVID-19 treatment: a mini-review. Front Public Health, 2020; 8: 252.

134. Baguley DM, Prayuenyong P. Looking beyond the audiogram in ototoxicity associated with platinum-based chemotherapy. Cancer Chemother Pharmacol, 2020; 85(2): 245-50. 